\title{
Treatment of drug dependence with Brazilian herbal medicines ${ }^{\#}$
}

\author{
Elisaldo A. Carlini*, Eliana Rodrigues, Fúlvio R. Mendes, Ricardo Tabach, Bruno Gianfratti
}

CEBRID - Centro Brasileiro de Informações sobre Drogas Psicotrópicas, Departamento de Psicobiologia, Universidade Federal de São Paulo, R. Botucatu, 862, $1^{\circ}$ andar do ECB, Vila Clementino, 04023-062, São

\author{
Paulo, SP, Brasil
}

RESUMO: “Tratamento da dependência de drogas com plantas medicinais brasileiras”. O tema "Plantas medicinais no tratamento de dependência" em um país deve ser precedido pela resposta a quatro questões: 1 . O país em questão possui biodiversidade suficiente para permitir a descoberta de remédios naturais úteis? 2. Seus habitantes possuem tradição e cultura de procurar e utilizar recursos da natureza para aliviar e curar doenças, incluindo dependência de drogas? 3. O problema de dependência de drogas está presente no país em questão? 4. Seus habitantes reconhecem e diagnosticam a dependência de drogas como um sério problema? O álcool é, de longe, o mais sério problema de saúde quando o assunto abuso de drogas é considerado, atingindo toda a sociedade brasileira, incluindo os índios. Ao contrário, outras drogas podem ser consideradas como problemas menores e não são o foco principal deste artigo. As pessoas vivendo nas terras brasileiras mais isoladas não têm acesso ao sistema público de saúde. Conseqüentemente, estas pessoas procuram tratamento com curandeiros e raizeiros; ou, no caso dos indígenas, com os shamans. Estes doutores populares não conhecem a medicina e terapêutica acadêmicas e recorrem a plantas locais para tratar as diferentes patologias que acometem seus pacientes. Entretanto, o abuso e dependência de álcool não são vistos por eles como problemas de saúde segundo as regras e critérios da medicina acadêmica. Um levantamento foi feito em diversos livros brasileiros, teses sobre fitoterapia e alguns bancos de dados. Os resultados de tal pesquisa foram frustrantes. Não foram encontrados artigos de autores brasileiros sobre o uso de plantas para o tratamento de dependência de drogas nos bancos de dados consultados e apenas três notas muito curtas em um livro clássico escrito por Shultes e Raffauf (1990). Dos livros brasileiros sobre o uso popular de plantas medicinais, foram obtidas dez menções: a maioria delas sobre o tratamento de problemas relatados ao álcool e duas delas a respeito do tratamento da dependência de "Ayahuasca".

Unitermos: Plantas medicinais, dependência de drogas, alcoolismo, Brasil, tratamento, biodiversidade.

\begin{abstract}
The topic "Herbal Medicines in the Treatment of Addictions" in a country must be preceded by answers to four questions: 1 . Does the country in question possess a biodiversity rich enough to allow the discovery of useful medicines? 2. Do local people have tradition and culture to look for and use resources from Nature to alleviate and cure diseases, including drug dependence? 3. Is drug dependence (or addiction) present in the country in question? 4. Do people of that country recognize and diagnose such problem as a serious one? Alcohol is, by far, the most serious health problem when drug abuse is considered, reaching all of Brazilian society, including the Indians. On the contrary, other drugs may be considered as minor problems and they are not the main focus of this manuscript. The people living in Brazilian hinterland don't have access to public health systems. Consequently, these people seek assistance from "curandeiros" and "raizeiros"; the Indians are assisted by the shaman. These "folk doctors" do not know the academic medicine and therapeutics, and resort to the local plants to treat different ailments of their patients. Furthermore, alcohol abuse and dependence are not recognized by them, according to the rules and criteria of academic medicine. We have conducted a survey in many Brazilian books, Thesis concerning phytotherapy, and several databank. The results of such searches were very disappointing. No published papers from Brazilian authors concerning the use of plants for the treatment of addictions were found in the databases and there were only three very short notes in the masterly book written by Shultes and Raffauf (1990). From the Brazilian books on folk medicine employing medicinal plants, ten mentions were disclosed: most of them dealing with treatment of alcohol problems and two to counteract "Ayahuasca" dependence.
\end{abstract}

Keywords: Medicinal plants, drug dependence, alcoholism, Brazil, treatment, biodiversity. the treatment of addiction" - London, 2006. 


\section{INTRODUCTION}

The topic "Herbal Medicines in the Treatment of Addictions" in a given country must be preceded by answers to four questions:

1. Does the country in question possess a biodiversity rich enough to allow the discovery of useful medicines?

2. Do local people have tradition and culture to look for and use resources from Nature to alleviate and cure diseases, including drug dependence?

3. Is drug dependence (or addiction) present in the country in question?

4. Do people of that country recognize and diagnose such problem as a serious one?

It is obvious that the more positive answers are found for a country, the larger will be the possibility of having plants possibly active for the treatment of Drug Addiction or other diseases. However, as it will be shown in the present study, Brazil scores high performance in answering these four questions; but, the number of plants used in the Brazilian folk medicine for such purpose is disappointing and even so there are only a few, if not none, scientific studies to prove the alleged therapeutic claim.

Question 1 - Does the country in question possess a biodiversity rich enough to allow the discovery of useful medicines?

Brazil, with a territory of 8.5 millions square kilometers, is considered one of the six mega diversities. Brazil alone has more than 56,000 plant species distributed among its five different ecosystems, almost $19 \%$ of the world flora (Giulietti et al., 2005). Therefore, is obvious that an exuberant flora is present in the Brazilian territory.

Question 2 - Do local people has tradition and culture to look for and use resources from nature to alleviate and cure diseases, including drug dependence?

The present Brazilian population is above the 180 million inhabitants. It was initially composed of European Caucasians (the Portuguese discoverers and others), the local Indian population (near 5 million when the Portuguese first arrived, in April 1.500) and black slaves (also millions). Due to the very intense melting of these three groups it emerged the "caboclos" who are either descendents of Caucasians and Indians (also called "mamelucos"); Caucasians and blacks (known as "mulatos") or blacks and Indians (the "cafusos").

The Brazilian Indians are divided in 220 groups (Nations) speaking 180 different languages; many of them still live in very close contact with Nature. The "caboclos" are peasants living scattered in a vast amount of the Brazilian territory and received the heritage of three different cultural influences (Blacks, Caucasians and Indians); their herbal medicine is rich indeed. Finally, it is worth mentioning the "quilombolas" black citizens, descendents from former slaves who had fled, in last centuries. These runway slaves went to backlands, far away from de "Brazilian civilization", organizing themselves in small villages, called "Quilombos". Their descendents still live in those areas, preserving old habits and rituals, rich in folk medicine.

Question 3 - Is drug dependence (or addiction) present in the country in question?

Alcohol is by far the most serious health problem when drug use is considered, reaching all of the Brazilian society, including the Indians.

The second national household survey conducted in 2005 revealed that $12.3 \%$ of the $12-65$ years old population could be defined as dependent on alcohol, according the definition of SAMSHA (CEBRID, 2006, p.33).

A 2004 survey on admission of patients to 160 Brazilian hospitals revealed the following figures: alcohol represented $75.7 \%$ of the admissions, followed by cocaine $4.1 \%$ and Marihuana $1.3 \%$; admission due to other drugs was negligible (unpublished data). For sure inhabitants of Brazilian backlands far way from the cities, such as hundreds of thousands of Indians and millions of "caboclos" are not represented in this survey. However, there are many indications showing that alcohol is a serious problem among those individuals (Viertler, 2002; Souza; Oliveira; Kohatsu, 2003; Ferreira, 2002).

Question 4 - Do people of that country recognize and diagnose such problem as a serious one?

Medical and psychology schools teach and consequently Brazilian psychiatrists and other professionals of health care area are well acquainted with criteria for diagnosing dependence such as CID10 or DSM-IV systems, and modern therapeutic tools are available to treat drug dependence. That is, pharmacotherapy of drug dependence in Brazil is based on drug commonly used world wide.

A different picture emerges in the Brazilian hinterland in which it is difficult (if not impossible) to have access to public health systems. Consequently, the "caboclos" living far way from the cities seek assistance from "curandeiros" and "raizeiros"; the Indians are assisted by the shaman (healer men; "feiticeiros"). These "folk doctors" do not know the academic medicine and therapeutics; they resort to the local plants to treat different ailments of their patients.

Furthermore, alcohol abuse and dependence are not recognized by them according to the rules and criteria of academic medicine. Some Indians, for example, although involved in heavy alcohol drinking, usually declare alcohol as a "white man problem" and their shaman do not treat them.

The "caboclo", on the other hand, recognize the following problems and consequent behavior as alterations from persons involved with alcohol use:

- "fissura"(craving) - the person is desperately looking for alcohol.

- "de porre" (acute intoxication) the person is

Rev. Bras. Farmacogn. Braz J. Pharmacogn 16(Supl.):dez. 2006 
unable to walk steadly and sometimes lies on the floor.

- "bebum"; "viciado" - the person is dependent on alcohol.

- "ressaca" or "carraspana" - the next day hangover.

\section{MATERIAL AND METHODS}

\section{Literature Search}

Surveys were conducted by searching international and national databanks and by direct consultation to several Brazilian books on medicinal plants from CEBRID library.

\section{Databanks}

- PubMed database under the key-words "plants and dependence" and "alcoholism and treatment".

- $\boldsymbol{C E B R I D}$ (www.cebrid.epm.br). This bank contains scientific articles published on several aspects of psychotropic drugs by Brazilian authors. This bank does not contain the key word "plants". Thus, the key words used were: Alcoholism and Treatment; "Maconha" (Marihuana) and Treatment; Opiates and Treatment; Amphetamine and Treatment; Cocaine and Treatment; and Solvents and Treatment.

Other databanks: The survey on the following databases was made using traditional populations as key words. The result of the search was analyzed looking for plants used for drug dependence.

- NUPAUB-USP database (Research Center on Human Population and Wetlands in Brazil - University of São Paulo - http://www.usp. $\mathrm{br} /$ nupaub/) under the key-words: "Indians and plants"; "river-dwellers and plants" and "AfroBrazilian and plants".

- CAPES database (mainly Thesis) under the keywords: "Indians and plants"; "river-dwellers and plants" and "Afro-Brazilian and plants".

- DEDALUS- USP database under the keywords: "Indians and plants"; "river-dwellers and plants" and "Afro-Brazilian and plants".

Survey on Brazilian Books

A t otal of 76 books from the CEBRID library

Table 1. Brazilian plants used for treatment of drug dependence.

\begin{tabular}{|c|c|c|c|}
\hline $\begin{array}{l}\text { Scientific name (popular } \\
\text { name) }\end{array}$ & Family & Use & Reference \\
\hline Ilex guayusa Loesener & Aquifoliaceae & $\begin{array}{l}\text { Employed to prevent hangover and to } \\
\text { eliminate the bitter taste in the ayahuasca } \\
\text { users. }\end{array}$ & $\begin{array}{l}\text { Schultes; Raffauf, } \\
1990\end{array}$ \\
\hline $\begin{array}{l}\text { Capsicum chinense } \\
\text { Jacquin (giimo) }\end{array}$ & Solanaceae & $\begin{array}{l}\text { it can help people to overcome the effects } \\
\text { of ayahuasca intoxication }\end{array}$ & $\begin{array}{l}\text { Schultes; Raffauf, } \\
1990\end{array}$ \\
\hline Duroia genipoides & Rubiaceae & the decoction from leaves of this plant is & Schultes Raffauf, 1990 \\
\hline Hookerf fil. ex. K. & & used by the Tikuna indians to reduce the & \\
\hline Schuman & & $\begin{array}{l}\text { headache and hangover following } \\
\text { alcoholic intoxication }\end{array}$ & \\
\hline $\begin{array}{l}\text { Turnera diffusa Willd } \\
\text { (damiana) }\end{array}$ & Turneraceae & indicated to counteract alcoholism & Mors et al., 2000 \\
\hline $\begin{array}{l}\text { Capsicum annum L. } \\
\text { (pimentão) }\end{array}$ & Solanaceae & $\begin{array}{l}\text { powder of the fruits of this plant is } \\
\text { employed in the treatment of the alcohol } \\
\text { delirium tremens }\end{array}$ & $\begin{array}{l}\text { Gazeta Médica da } \\
\text { Bahia, 1867; Balmé, } \\
1978\end{array}$ \\
\hline $\begin{array}{l}\text { Passiflora quadrangularis } \\
\text { L. (maracujá-açu) }\end{array}$ & Passifloraceae & $\begin{array}{l}\text { used for treatment of chronic alcoholism } \\
\text { and delirium tremens }\end{array}$ & $\begin{array}{l}\text { Alzugaray; Alzugaray, } \\
\text { 1983; Balbachas, 1957; } \\
\text { Balbach, n.d.; Fossat, } \\
\text { n.d. }\end{array}$ \\
\hline $\begin{array}{l}\text { Paullinia cupana ex Mart. } \\
\text { (guarana) }\end{array}$ & Sapindaceae & used to alleviate the alcohol hangover & Rose, 1978 \\
\hline Psychotria viridis Ruiz \& & Rubiaceae and & It seems that "the ritualized use of & Labigalini Junior et al., \\
\hline $\begin{array}{l}\text { Pav. and Banisteriopsis } \\
\text { caapi (Spruce ex Griseb.) } \\
\text { C.V. Morton (Ayahuasca, } \\
\text { Santo Daime) }\end{array}$ & Malpighiaceae & $\begin{array}{l}\text { ayahuasca may be a therapeutic } \\
\text { alternative for alcoholism" }\end{array}$ & 1995; Grob et al., 1996 \\
\hline $\begin{array}{l}\text { Manihot esculenta Crantz } \\
\text { (mandioca) and Spilanthes } \\
\text { acmella (L.) Murray } \\
\text { (jambu) }\end{array}$ & $\begin{array}{l}\text { Euphorbiaceae and } \\
\text { Asteraceae }\end{array}$ & $\begin{array}{l}\text { people use to drink the "tucupi", a } \\
\text { mixture of "mandioca" and "jambu" to } \\
\text { rid them out of the unpleasant symptoms } \\
\text { of the alcoholic hangover }\end{array}$ & $\begin{array}{l}\text { Personal } \\
\text { communication }\end{array}$ \\
\hline
\end{tabular}


were examined. The index words searched(when available) were: alcoholism, delirium tremens, dependence, drug abuse, tobacco use, hangover (in Portuguese: "alcoolismo", delirium tremens, "dependência", "abuso de drogas", "tabagismo" and "ressaca", respectively).

\section{RESULTS}

\section{Findings in the international and national databanks}

- PubMed - 212 publications were disclosed: none of them from Brazil or South America. Two articles referring to the Peyote (Lophophora williamsii (Lem. ex Salm-Dyck) J.M. Coult.), the Mexican cactus of Central America recommended for treatment of alcoholism.

- CEBRID - A total of 459 articles were selected: only three of them were on the use of plants: 2 articles on Marihuana use for crack dependence (Labigalini Junior; Rodrigues; Silveira, $1998 ; 1999)$ and one referring to the use of “Ayahuasca” for alcohol dependence (Labigalini Junior; Miranda; Tacla, 1995).

- CAPES, NUPAUB and DEDALUS - The publications disclosed with traditional populations did not reveal plants used to counteract drug dependence.

\section{Findings in books dealing with medicinal plants}

A total of 76 such Brazilian books were perused and produced a total of 11 indications of plants used for drug problems (Table 1); two of them claimed use against ayahuasca intoxication [beverage made up of Banisteriopsis caapi (Spruce ex Griseb.) C.V. Morton and Psychotria viridis Ruiz \& Pav.] and nine other plants for the treatment of alcoholism. However, these indications are very short mentions of the use, without any further scientific information.

Furthermore, the survey carried out in Brazilian books revealed the following non-Brazilian species, although they are not the focus of this work (Balbachas, 1957; Cruz, 1982; Morgan, 1982; Alzugaray; Alzugaray, 1983; Iamoni, 1997):

- Anti-alcohol: coffee (Coffea arabica L.), lemon (Citrus limonum Risso), "noz-vômica" (Strychnos nux-vomica L.), kale (Brassica oleracea L.) and parsley (Petroselinum sativum Hoffm.);

- Anti-tabagism: garlic (Allium sativum L.), Nasturtium officinale R. Br., Centaurea centaurium L., Sisymbrium officinale (L.) Scop, Fumaria officinalis L., Citrus aurantium L., Melissa officinalis L., Juglans regia L. and Thymus vulgaris L.;

- Delirium tremens: Cannabis indica Lam.

\section{DISCUSSION}

The two Amazonian plants used for treatment of Ayahuasca intoxication were reported by Schultes; Raffauf (1990): Ilex guayusa Loesener and Capsicum chinense Jacquin, used by Peruvian Indians and Ecuadorian Indians, respectively. Interestingly, the beverage Ayahuasca used in religious rituals ("Santo Daime", "União do Vegetal") is used by followers to remit from their previous use of alcohol and cigarettes (see Grob et al., 1996 and Carlini, 2003 for further details).

Among the plants used by Brazilian people to treat alcohol problems, Passiflora quadrangularis L. was the most cited. A tea from leaves is indicated as "tranquilizer and sedative" for nervous breakdown and insomnias; it is also used for treatment of chronic alcoholism and delirium tremens (Alzugarai; Alzugaray, 1983; Balbachas, 1957; Balbach, n.d.; Fossat, n.d.). It calls the attention that Passiflora incarnata L. is worldwide used as an anxiolytic and sedative phytomedicine (Speroni et al., 1996; Dhawan; Dhawan; Sharma, 2004) and people suffering from stress and anxiety are more vulnerable to alcohol abuse (NIDA, 2005). Furthermore, $P$. incarnata extracts are also used for treatment of chronic alcoholism (Dhawan; Kumar; Sharma 2002) and to alleviate opiate withdrawal symptoms (Akhondzadeh et al., 2001). According to Dhawan; Kumar; Sharma (2002) a benzoflavone moiety from $P$. incarnata reduced the abstinence withdrawal. It seems therefore that both $P$. quadrangularis and $P$. incarnata have similar clinical use profile. Concerning this similarity it is worth mentioning the recent demonstration that $P$. quadrangularis extracts have anxiolytic properties (Castro et al., 2006).

A second plant to be mentioned is Capsicum annum L., whose use to treat alcohol delirium tremens was in a note published near 140 years ago (Gazeta Médica da Bahia, 1867, p.179). The note quoted an article published in a certain "Med. press and Circular" describing 60 to 80 successful treatments of delirium tremens patients. According to Balmé (1978), Capsicum annuun is considered as a valuable medicine to treat alcoholism when mixed with powder of "cascarilha" (Croton sp.) and of "ruibarbo" (Rheum palmatum L.).

The decoction from leaves of Duroia genipoides Hookerf fil. ex. K. Schuman, according to Schultes; Raffauf (1990), is used by the Tikuna Indians (Amazon Area, North of Brazil) to reduce the headache, "ressaca" (hangover) following alcoholic intoxication. However, the plant is also said to be poisonous.

Turnera diffusa Willd. ex Schult., is a cosmopolitan plant, from São Paulo to Amazon states in Brazil, considered as a panacea due to its many folk therapeutic indications, among them nervous disorders, aphrodisiac and alcoholic abuse (Mors; Rizzini; Pereira, 2000). This general use is similar to that of guarana (Paullinia cupana Kunth.) mainly used as tonic and stimulant with a profile that remembers an adaptogen 
(Carlini, 1991). There are some examples of adaptogen plants used against drug dependence, like Panax ginseng C.A. Mey. and Withania somnifera (L.) Dunal (Kim; Jang; Lee, 1990; Kulkarni; Ninan, 1997). The Amazonian Brazilian plant guarana, according to Jeanne Rose's Herbal (Rose, 1978) is used to alleviate the alcohol hangover.

Finally, is interesting to quote one prescription with two plants given by a Doctor from Belém, Pará State. In north of Brazil, people use to drink a beverage named "tucupi", a mixture of Manihot esculenta Crantz (manioc, Brazilian popular name "mandioca") and Spilanthes acmella (L.) Murray ("jambu") to rid them out of the unpleasant symptoms of the alcoholic hangover (or "carraspana" as it is said in that Brazilian region). People believe that tucupi is more efficient than a famous medicine used in Brazil for the same ailment $\left(\right.$ Engov $^{\circledR}$ an association of acetylsalicylic acid, aluminum hydroxide, mepiramine maleate and caffeine). The roots of $M$. esculenta are scraped and the resulting paste is firmly pressed yielding a coarse milky liquid. This is boiled with leaves of "jambu", yielding the "tucupi". Recently a diet rich in "mandioca" and alcohol was co-administered to rats. The results showed a lower activity of hepatic enzymes and less histopatological changes, demonstrating that "mandioca" reduced the alcohol induced hepatic toxicity (Boby; Indira, 2004). "Jambu" besides being used as food flavoring has local anesthetic effect and is used in folk medicine for treatment of mouth ailments; spilanthol was isolated from it (Herdy; Carvalho, 1984). Preliminary work carried out in our laboratories showed that "jambu" extracts possess, as synthetic local anesthetics, a strong convulsant effect in mice (Table 2).

Among the non-Brazilian plants cited in this work, the coffee merits some notes. There is a negative correlation between coffee ingestion and cirrhoses incidence (Klatsky; Armstrong; Friedman, 1993), and possibly between coffee ingestion and alcohol abuse (Santos; Vieira; Lima, 1991), what support the folk indications that coffee is useful against acute alcohol intoxication (Cruz, 1982; Corrêa, 1984).

Alcohol dependence may be related to a deficiency of dopaminergic brain function (Tupala et al., 2001; Bowirrat; Oscar-Berman, 2005). It follows then that alcohol consumption could be a tentative of the alcoholic person to restore a dopaminergic hypofunction.

Our preliminary studies indicate that a coffee extract possess a dopaminergic effect (Mendes et al.,
2004/2005). If further confirmed this finding may help to understand some epidemiological observations indicating that alcohol consumption is smaller among regular coffee drinkers (Santos; Vieira; Lima, 1991; Flores; Andrade; Lima, 2000).

The present work shows that despite its rich biodiversity, Brazil has a few plants used to treat drug dependence problems. The few plants cited on the literature consulted have no studies concerning this activity (to counteract drug dependence or withdrawal). On the other hand, Hypericum perforatum L., Tabernanthe iboga Baill., Pueraria lobata (Willd.) Ohwi, among others, are examples of non Brazilian plants that have shown therapeutic potential against drug abuse (Carai et al., 2000; Rezvani et al., 2003; Zhang, 2004).

\section{REFERENCES}

Akhondzadeh S, Kashani L, Mobaseri, MD, Hosseini, MD, Nikzad, S, Khani, M 2001. Passiflower in the treatment of opiates withdrawal: a double-blind randomized controlled trial. J Clin Pharm Ther 26: 369-373.

Alzugaray D, Alzugaray C 1983. Plantas que curam (2 volumes). São Paulo: Três.

Balbach A (n.d.). A flora nacional na medicina doméstica.11.ed. (2 volumes). São Paulo: MVP.

Balbachas A 1957. As plantas curam. São Paulo: Missionária.

Balmé F 1978. Plantas Medicinais. São Paulo: Hemus.

Boby RG, Indira M 2004. Effect of co-administration of cassava (Manihot esculenta Crantz) rich diet and alcohol in rats. Indian J Physiol Pharmacol 48: 41-50.

Bowirrat A, Oscar-Berman M 2005. Relationship between dopaminergic neurotransmission, alcoholism, and reward deficiency syndrome. Am J Med Genet B Neuropsychiatr Genet 132: 29-37.

Carai MAM, Agabio R, Bombardelli E, Bourov I, Gessa GL, Lobina C, Morazzoni P, Pani M, Reali R, Vacca G, Colombo G 2000. Potential use of medicinal plants in the treatment of alcoholism. Fitoterapia 71: S38-S42.

Carlini EA 1991. Efeito adaptógeno ou resistógeno de algumas plantas. In: Buchillet, D. (ed) Medicinas tradicionais e medicina ocidental na Amazônia. Belém: Edições Cejup, p.45-59.

Carlini EA 2003. Plants end the central nervous system. Pharmacol Biochem Behav 75: 501-512.

Castro PCF, Hoshino A, Silva JC, Mendes FR 2006. Possible anxiolytic effect of two extracts of Passiflora quadrangularis L. in experimental models. Phytother Res No prelo.

CEBRID 2006. II Levantamento domiciliar sobre o uso de drogas psicotrópicas no Brasil: estudo envolvendo

Table 2. Median effective dose $\left(\mathrm{ED}_{50}\right)$ and its limits $95 \%$ confidence of clonic convulsions in mice.

\begin{tabular}{l|ll}
\cline { 2 - 3 } & Drug & $\mathrm{ED}_{50}(\mathrm{mg} / \mathrm{kg})$ \\
\cline { 2 - 3 } & Bupivacain & $50(42-64)$ \\
& Lidocain & $120(81-173)$ \\
& Pentilenetetrazol & $58(29-118)$ \\
& Jambu extract & $92(52-116)$ \\
\cline { 2 - 3 } & & \\
\hline 694 & Rev. Bras. Farmacogn. & \\
& Braz J. Pharmacogn. &
\end{tabular}


as 108 maiores cidades do país - 2005. São Paulo: CEBRID. p.33.

Corrêa MP 1984. Dicionário das plantas úteis do Brasil e das exóticas cultivadas Vol.1, Rio de Janeiro: Ministério da Agricultura, Instituto Brasileiro de Desenvolvimento Florestal.

Cruz GL 1982. Dicionário das plantas úteis do Brasil. 2.ed. Rio de Janeiro: Civilização Brasileira.

Dhawan K, Dhawan S, Sharma A 2004. Passiflora: a review update. J Ethnopharmacol 94: 1-23.

Dhawan K, Kumar S, Sharma A 2002. Suppression of alcoholcessation-oriented hyper-activity by the benzoflavone moiety of Passiflora icarnata Linneaus in mice. $J$ Ethnopharmacol 81: 239-244.

Ferreira LO 2002. O impacto do uso abusivo de bebidas alcoólicas sobre a pessoa Mbyá-Guarani - RS. Ellus 2: 39-64.

Flores GB, Andrade F, Lima DR 2000. Can coffee help fighting the drug problem? Preliminary results of a Brazilian youth drug study. Acta Pharmacol Sin 21: 10591070 .

Fossat AG (n.d.). A cura pelas plantas. Pelas folhas, pelos frutos, pelas raizes. 4.ed. Rio de Janeiro: Eco.

Gazeta Médica da Bahia (1867) 1974. Tratamento do delirium tremens pela pimenta (Capsicum annuum). Brasiliensia Documenta IX. São Paulo: Escola Paulista de Medicina, Departamento de Bioquímica e Farmacologia, p.179.

Giulietti AM, Harley RM, Queiroz LP, Wanderley MGL, Berg CVD 2005. Biodiversidade e conservação das plantas no Brasil. Megadiversidade 1: 52-61.

Grob CS, McKenna DJ, Callaway JC, Brito GS, Neves ES, Oberlaender G, Saide OL, Labigalini E, Tacla C, Miranda CT, Strassman RJ, Boone KB 1996. Human psychopharmacology of hoasca, a plant hallucinogen used in ritual context in Brazil. J Nerv Ment Dis 184: 86-94.

Herdy GVA, Carvalho AP 1984. Ação do espilantol (extraído do jambu) sobre a atividade elétrica do coração de coelho. Eletrocardiograma experimental. Arq Bras Cardiol 43: 315-320.

Iamoni R 1997. A cura pelos remédios caseiros. Rio de Janeiro: Adiouros.

Kim HS, Jang CG, Lee MK 1990. Antinarcotic effects of the standardized ginseng extract G115 on morphine. Planta Med 56: 158-163.

Klatsky AL, Armstrong MA, Friedman GD 1993. Coffee, tea and mortality. Ann Epidemiol 3: 375-381.

Kulkarni SK, Ninan I 1997. Inhibition of morphine tolerance and dependence by Withania somnifera in mice. $J$ Ethnopharmacol 57: 213-217.

Labigalini JE, Miranda C, Tacla A 1995. O uso ritualizado de ayahuasca: alternativa terapêutica para alcoolismo. Anais do Seminário Internacional O Uso e o Abuso de Drogas. Salvador, Brasil. p.107.

Labigalini JE, Rodrigues LR, Silveira DX 1998. Redução de danos no uso de maconha por dependentes de crack. Anais do S.O.S. Crack Prevenção e Tratamento. São Paulo, Brasil. p.40.

Labigalini JE, Rodrigues LR, Silveira DX 1999. Therapeutic use of cannabis by crack addicts in Brazil. J Psychoactive Drugs 31: 451-455.

Mendes FR, Mattei R, Tabach R, Rodrigues E, Carlini EA
2004/2005. Avaliação de um extrato de café (BST 09101) em modelos animais de depressão e síndrome de abstinência à morfina. Arq Bras Fitomed Cient 2: 56-66.

Morgan R 1982. Enciclopédia das ervas e plantas medicinais. São Paulo: Hemus Ltda.

Mors WB, Rizzini CT, Pereira NA 2000. Medicinal plants of Brazil. Michigan: Reference Publications.

Nida. - http://www.nida.nih.gov/stressanddrugabuse.html, accessed in December of 2005.

Rezvani AH, Overstreet DH, Perfumi M, Massi M 2003. Plant derivatives in the treatment of alcohol dependency. Pharmacol Biochem Behav 75: 593-606.

Rose J 1978. Herbs \& Things: Jeanne Rose's herbal. New York: Grosset \& Dunlap Workman Publishing Company.

Santos RM, Vieira S, Lima DR 1991. Effects of coffee in alcoholics. Ann Intern Med 115: 499.

Schultes RE, Raffauff RE 1990. The healing forest: medicinal and toxic plants of the North West Amazonia. Oregon: Dioscorides Pres. Portland.

Souza JÁ, Oliveira M, Kohatsu M 2003. O Uso de bebidas alcoólicas nas sociedades indígenas: algumas reflexões sobre os Kaingang da Bacia do Rio Tibagi, Paraná. In: Coimbra Jr., Carlos, E.A. (org). Epidemiologia e saúde dos povos indígenas no Brasil. Rio de Janeiro: FioCruz / ABRASCO, p.149-167.

Speroni E, Billi R, Mercati V, Boncompag E, Toja F 1996. Sedative effects of crude extract of Passiflora incarnata after oral administration. Phytother Res 10: S92-S94.

Tupala E, Hall H, Bergström K, Särkioja T, Räsänen P, Mantere T, Callaway J, Hiltunen J, Tiihonen J 2001. Dopamine $\mathrm{D}_{2} / \mathrm{D}_{3}$-receptor and transporter densities in nucleus accumbens and amygdale of type 1 and 2 alcoholics. Mol Psychiatry 6: 261-267.

Viertler RB 2002. Convívio interétnico e alcoolismo entre os Borro: resultados de uma pesquisa. Tellus 2: 9-38.

Zhang ZJ 2004. Therapeutic effects of herbal extracts and constituents in animal models of psychiatric disorders. Life Sci 75: 1659-1699. 